\title{
Currency Wars, Recession Policies and the Overvalued Euro are to be Blamed for the Modern Greek Tragedy
}

\author{
Theodore Katsanevas*
}

\begin{abstract}
:
In this paper we argue that, Modern Greek Tragedy is mainly due to the overvalued euro in combination with the strict austerity policies imposed by Berlin. Greece also pays the price of the currency war between the dollar and the euro. The latter puts a heavy burden upon the country's economic competitiveness as a costume that does not fit the Greek economy, which is mainly based on tourism that requires a labour-intensive production process.

The deadlocks of strict monetary and income's policies, accelerates the upcoming economic thunderstorm, the spiral of recession, the increase in unemployment, the brutal reduction of wages and pensions, the further fall of GDP and the increase of the debt. The always renewed fatal economic forecasts, simply postpone the explosion of the deadlock. Basic economics in theory and in practice are being depreciated.

One wonders if there are economists, neoliberals, not to mention, Keynesians and/or radicals that, may support the possibility of an economic recovery under deep recession policies and the existence of a hard currency such as the euro. Trapped under the Berlin's political prison and the euro zone fetish, Greece continues to follow its tragic road on the grounds that there is no alternative. Yet, in democracies there are no dead ends. If an economic policy is proven to be wrong and catastrophic, the best alternative is to change it.
\end{abstract}

Key Words: Financial crisis, Greek tragedy.

*Professor Emeritus University of Piraeus, Greece tkats@yahoo.gr 


\section{Currency Wars and Consequences for Greece}

The Canadian economist Robert Mundell won a Nobel Prize in 1999 for his analysis on monetary and fiscal policies under different schemes of exchange rates, associated with the issue of optimal currency areas (Mundel, 1961). He is considered the father of the euro, since he designed it and was strongly in favor of its creation. Clearly though, he did not anticipate the distortion that was caused by the establishment of a common currency in countries with distinct economic structure, without having a central balancing economic and political umbrella. Many, if not the majority of internationally leading economists, seem to share the same views on the adverse operation of the euro zone ${ }^{1}$. Besides theoretical opinions, the euro zone countries, primarily Greece, followed by the other peripheral countries, are lacking substantially with regard to their growing potential compared to the rest of the world.

Berlin, contrary to Washington and the IMF, maintains a strict enforcement of the Eurozone's rules and of harsh policies leading to further recession; it wishes to create a small strong core of countries using the euro, which will compete with the dollar and replace it as exchange currency in international transactions. This little-known "currency war" between the dollar and the euro appears to account for Berlin's fixation on keeping a high euro exchange rate. Berlin wants Greece to leave the euro zone. The latter, due to its enormous debts as well as because of its different

\footnotetext{
${ }^{1}$ Among the worldwide leading economists, economic analysts, University professors who share more a less similar views are the following:

Paul Krugman (Nombel prize), Josef Stiglitz (Nombel prize), Hans Werner Sinn (iFo, Institut e of Economic Research), Kenneth Rogoff (Harvard), Noam Chomski

(MIT), Simon Johnson (MIT), Martin Felstein (Harvard), John Hekman (FTI, Harvard,MIT), Nurel Rubini (Global Economics), Marcello de Cecco (Parma University, Italy), Jayati Ghosh,(Nehru University, India), Ross McLeod (National Australian University ), Otmar Ising (economist, European Central Bank), Zoao Ferreira do Amaral (University of Lisbon, Portugal), Alexander Dilger (university of Munster), Alain Parguez (Université de Franche) Joachim Starbatty (University of Koln|), Helmut Schlesinger (ex President Budesbang), Naomi Klein (writer, USA), Michael Fooks (economic analyst), Stefan Xompourg (ex Bundesatag), Nouriel John Weeks (SOAS, London University), Simon WrenLewis (Oxford University), Lothar Mayer (University of Harbourg), Simon Drake and George Friedman (Statforr Institute), Jürgen Kaizer (economic analyst, USA), Lisa Mittendrein (Attac, Austria), Alan Sked (L.S.E., England), Dirk Muller (economic analyst, writer, Berlin), Lucke (University of Humburg) Mark Roche (economic analyst), François Asselineau (UPR, France), Opa Kapijimpanga (AFRODAD), Francisco La Manna (Italian economist), Bernd, Gerd Robanus (economist, AfD), Dean Beaton (CEPR), Amol Rajan (The Independent), Konrad Adam (economic analyst, AfD), Johan Van Overtveldt, (economist, writer), Zack Sapir (economic analyst, France), Greg Palast (economic analyst,

Observer), George Freedman (Statfort Institute), Rotzer Bootle (economist, Wolfson prize, G. Briain) etc.
} 
economic structure, is unable to follow the strict euro zone rules. If Berlin accepts to loosen euro zone rules for Greece, then this will have a domino effect on the other Southern countries as well and the euro will lose the war. "If you want to keep the euro at any cost, you will have to pay that cost" is what they tell us.

On the contrary, Washington with the support of France, while needs Germany to remain strong and function as a bulwark against the Russian bear, does not want it to become powerful enough to be able to question the US leadership in the western world and the global economy ( Muler, 2013). Furthermore, the US does not accept the replacement of the dollar with the euro, as an exchange and reserve currency for international transactions. Unfortunately, the Greek governments backed by the county's economic and media elit, have chosen to place Greece under the "protection" of Washington. So, the USA insists on maintaining a rather loose euro zone, which is further facilitated by the week Greek hoop in euro zone chain.

As James Rickards writes in his revealing book Currency Wars' "today we are going through a new currency war, whose consequences are much worse than the issues arisen from the enforcement of the gold standard. In this war, countries steal the development potential of other countries through the devaluation of their currencies" (Richards, 2014). This is exactly the case in Greece, where the high exchange rate of the euro along with other factors, such as huge discrepancies in taxation, lending, interests, etc. destroy the international competitiveness of the Greek economy.

\section{The Negative Effects of the Euro to the Greek Economy}

The overvalued euro mainly favors the countries that create high technology and innovation products. For instance, when a product such as a new effective medicine safeguards its patent and cannot be copied for at least 20 years, its production cost may be trivial, but its sale price is extremely high. This allows for an absurd profit margin, since the labor and raw materials cost is significantly low. A modern magnetic resonance tomograph, for example one made by Siemens, is so expensive because its purchase is considered necessary in global markets. Its spare parts are also sold at an extremely high price, although their cost is almost nothing. In addition, Siemens, as well as other multinational corporations, are keeping a "well paid" network of buyers worldwide.

This is the reason why the hard, overvalued euro benefits countries that focus on technology and innovation such as Germany. So, the latter profits excessively through the highly expensive exports of technological products; zero or negative interest rates of bonds and deposits that collectively gathers from countries all around the world, since it is regarded as a safe investment destination. Conversely, Greece, even though it has an immense human scientific potential a large part of which has emigrated abroad, maintains as its main production orientation tourism and agriculture, which require a labor intensive production process. Therefore, a 
significant amount of workforce is needed but unable to reduce its cost below a certain point, so as the total production cost to be lower or equal to that of our competitors. The charge for a hotel room in Greece, due to the high exchange rate of the euro compared to other currencies, is almost double than in Turkey, Egypt, Bulgaria, Romania, Hungary etc.

Because of the hard, expensive euro, combined with the Common Agricultural Policy of the EU and the adverse effects of subsidies, Greek agricultural production, with a labor cost that reaches $70-80 \%$ of the total production cost, goes to waste. Oranges, lemons, cherries, olives fall from the trees and rot, as importing from Argentina, Morocco, Egypt, etc. is cheaper. Even the lowest-paid workers in the agriculture field, Greeks or immigrants, cost far more, since they get paid in euro, than workers in some other countries who get paid in a devaluated currency. If farm workers in Greece cost 25 euro minimum, in Turkey, where they get paid in Turkish liras, their cost is estimated at 10-15 euro approximately. Cost of life in the neighbor country is also lower due to the devaluated Turkish lira and the majority of consumer products bought by a Turkish employee are cheaper. In other words, the purchasing power of 20 euro in Greece corresponds to 10-12 euro in Turkey or Bulgaria (Katsanevas, 2016).

The fact that Bulgaria belongs to the EU but not to the Eurozone having its own devaluated currency, has led thousands of Greek companies to transfer their registered office there. This is further exacerbated by burdens from direct and indirect taxation for companies and private parties, which in Bulgaria are about half the amount compared to that in Greece. Greek truck drivers are replaced by Bulgarians, since the cost of life there is much lower and therefore, they receive a much lower compensation. Greek pensioners are moving to Bulgaria because their extremely low pension in euro has an increased purchasing power there. Numerous Greek consumers who reside near the borders with Albania, FYROM, Bulgaria and Turkey, go on one-day trips to these countries to buy low-cost products of any kind.

\section{The Impact of International Currency Exchange Rates}

In general, the international exchange rates are regulated in the basis of international trade agreements under the World Trade Organization and on the supply and demand of imported and exported goods and services. In reality though, trade agreements have dissipated and the policies followed by the central banks of various countries have now an essential role. The banks, employing several means and specifically supplying or withdrawing exchange currency, granting direct or indirect subsidies for exports, posing obstacles to imports and regulating interest rates, set currency exchange rates that are advantageous for their countries.

A typical example is China, which by keeping the yuan exchange rate at extremely low prices,despite western complaints and requests for change of policy, has burst forth in global markets and today its foreign - exchange reserves exceed 4 trillion 
dollars. The devaluation of the Chinese stock exchange market in the late 2015 ,actually reflects the strategy followed by the Chinese government, concerning the downward drift of yuan, in order to support its exports. China is less interested in this than in promoting its exports. Apart from the enormous economic and political size of the country, Chinese banks are controlled by the state and it is impossible for any cunning Goldman Sachs or international vulture funds to speculate on the yuan.

As Simon Johnson points out, "the underlying problem in the euro area is the exchange rate system itself - the fact that these European countries locked themselves into an initial exchange rate, i.e., the relative price of their currencies, and promised never to change that exchange rate. This amounted to a very big bet that their economies would converge in productivity - that the Greeks (and others in what we now call the "periphery") would, in effect, become more like the Germans”'(Jonshon, S., 2015)

Histogram 1. Germany's trade surplus vs Greece before and after the euro launch

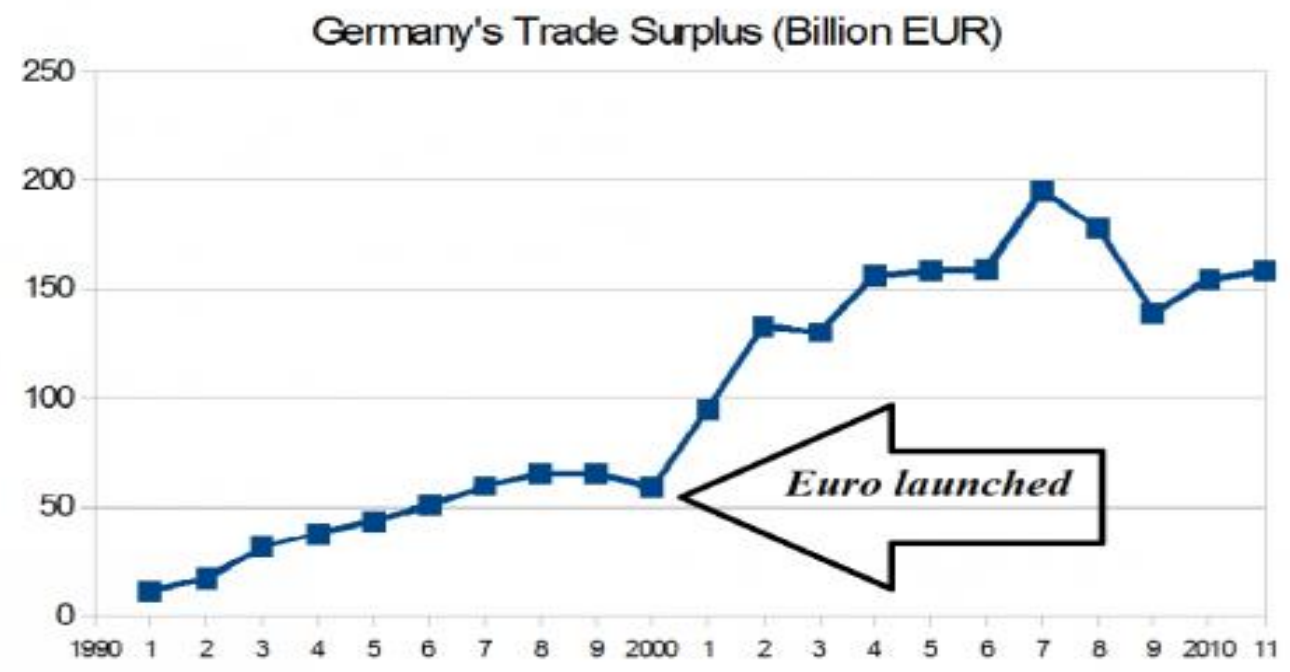

\section{Source: OECD}

In fact, the gap between German and Greek (and other peripheral countries) productivity increased, rather than decreased, over the last decade. Germany, as a result, developed a large surplus on its current account - meaning that it exports more than it imports. Without doubt, Germany vs Greece was the big winner of the euro zone creation as it is clearly shown in above Histogram 1 and not only.

During the initial euro zone years, countries like Greece, Spain, Portugal and Ireland, had large current account deficits; they were buying more from abroad than 
they were selling abroad. Their deficits were financed by capital inflows, including mainly from Germany. In theory, these capital inflows could have helped peripheral Europe invest, become more productive and "catch up" with Germany. In practice, the capital inflows, in the form of borrowing, created the pathologies that now roil European markets.

As Engelbert (2011) states, "the Greek debt crisis is often presented as a result of lack of fiscal discipline. There is some obvious truth in this as Greek deficits were higher than those of other Euro area countries. On the other hand, the fact that other peripheral countries (Portugal, Ireland, Italy, and Spain) are experiencing similar crises suggesting that a more general mechanism is at work. Indeed, we will argue, German export surpluses are a critical part of the story.

Histograme 2. Evolution of Greek GDP in relation to other euro zone countries

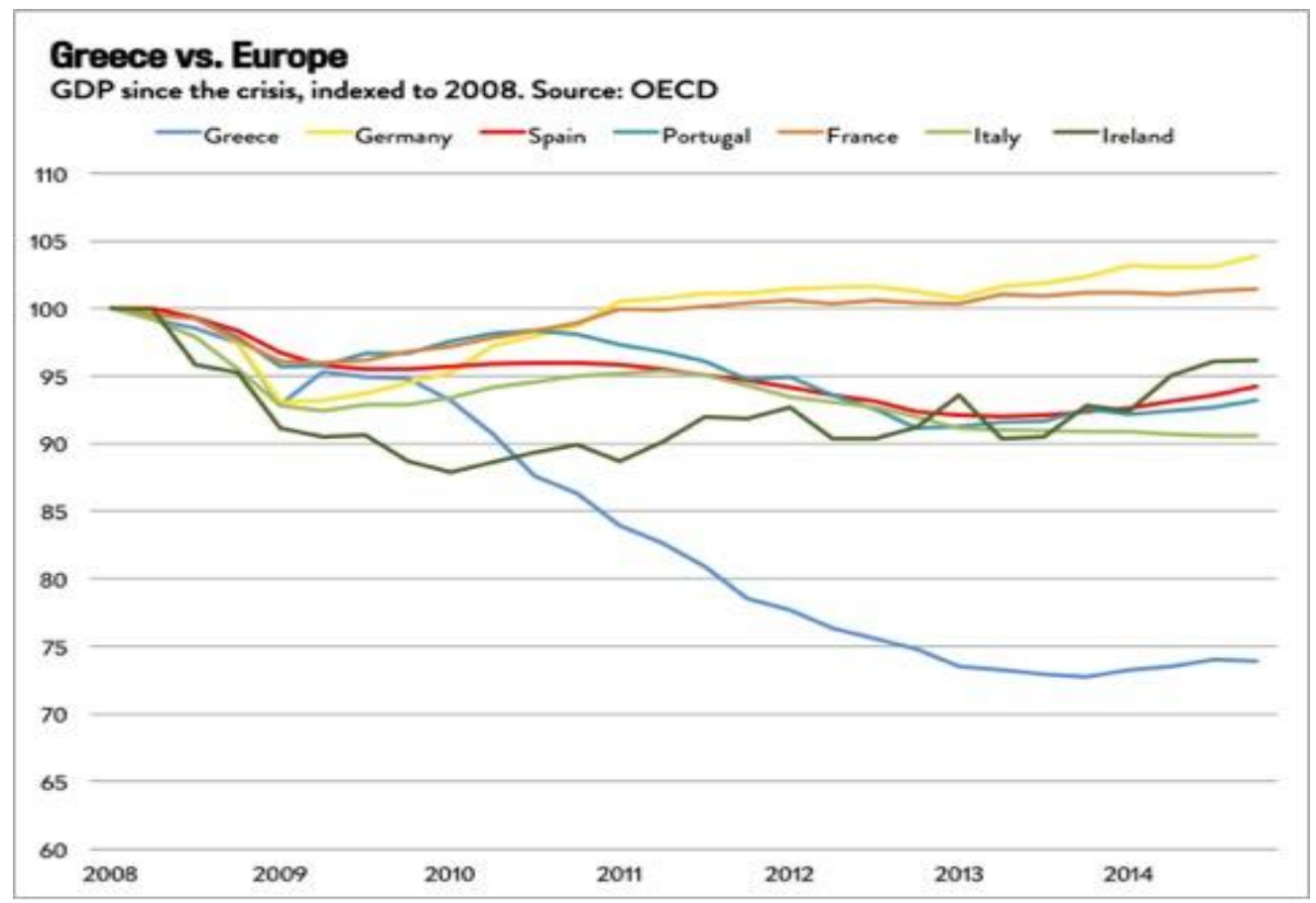

\section{The Gigantic Leap of the Greek Debt within the Eurozone}

A brief overview of official statistical data reveals the collapse of Greek economy within the euro zone ${ }^{2}$. Following a period of fabricated prosperity during 2002-2007

\footnotetext{
${ }^{2}$ Present data is drown from Hellenic Statistical Authority (ELSTAT), Manpower Employment Organization (OAED), Bank of Greece and Eurostat.
} 
which was systematically promoted through the increase of public debt and soaring escalation of lending to credit institutions, Greece faces eight years of economic decline from 2008 until today. There is no such precedent in modern economic world history, since even the great depression of 1929-32 in the US did not last more than six years (Histograms 2 and 3). In particular since 2008, public debt continues to rise whereas the national income deeply decreases without hope of recovery.

All economy indexes are collapsing. During the euro zone period, an enormous army of unemployed people was created, the largest percentage in Europe (Histogram 4). Employed people in 2002 were 4.353 million while in the end of 2015 they were decreased to 3.65 million. The unemployment percentage has more than doubled during 2002-2015; from 10-11\%, it has reached $24-26 \%$ in general population and over $40 \%$ in young adults. As a result, more than 500,000 young Greeks have immigrated abroad over the past six years. (ELSTAT Report, Sept.2016) Thousands of businesses are shutting or moving to other countries, such as Bulgaria, Cyprus, Great Britain, Switzerland, etc. in search of better tax and business conditions. According to Eurostat, between 2008-2015, 244.000 enterprises where shut down and 842.000 work places where lost.

Histogram 3. A comparison between current Greek depression and 1929 Great Depression

\section{Greek Recession vs. Great Depression}

United States (1929-1938) $\square$ Greece (2008-2014)

$100=\mathrm{GDP}$ at start of crisis

110

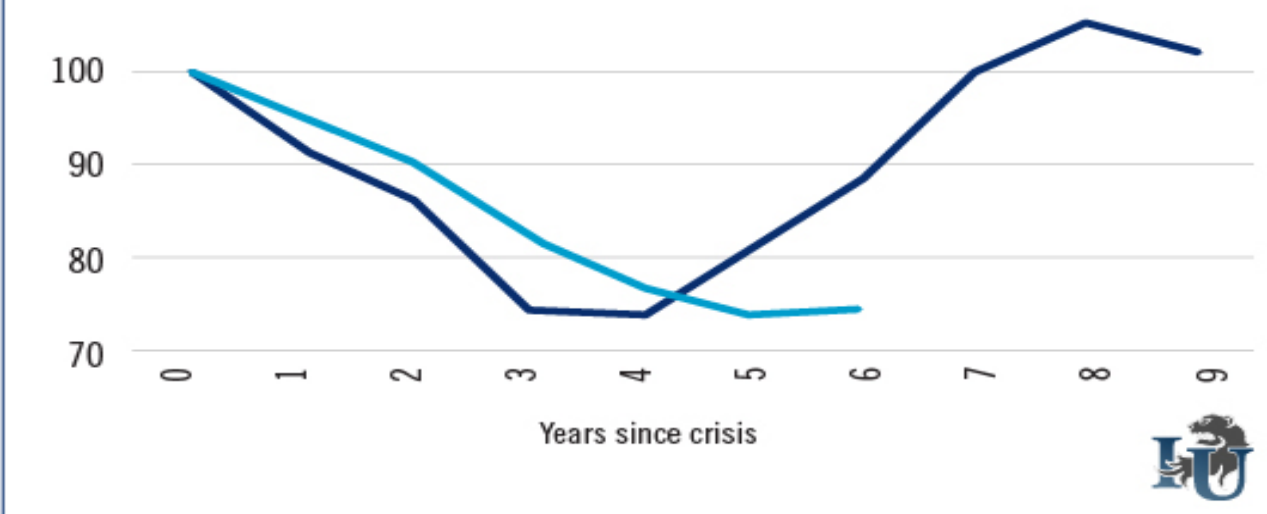

Source: The Pen World Tables 
The Histogram 5 disproves the popular myth that today's huge debt of Greece has been inherited from the past. As it is shown in the same Histogram which presents official data of the Eurostat, during the 1980s and the 1970s, the debt constituted an amount below 50\% of the GDP. In late 1980s it increased to 60\% and reached 75\% in the mid 1990s and approximately 100\% towards the end of that decade. It was within the euro zone though, that the debt took a quantum leap and reached $180 \%$ after 2008 and today it amounts well 200\% of GDP in accordance with the National Debt Org in May 2016.

Within the euro zone, the debt continued to increase and it will continue to do so, regardless of the recapitalization or the haircut (PSI) in 2012, by fleecing bonds of the Greek state and Greek citizens, seizing Greek banks in 2014 and 2015, arbitrarily selling out public property in 2016, the larcenous shrinkage of incomes through taxation and the decrease in pensions and wages. Since 2002, when Greece entered the euro zone and granted the right of currency issuance to the European Central Bank in Frankfurt, it lost its sovereignty and it turns again and again to the lenders for new loans in order to pay up the older ones. It is an endless spiraling of loans that are self-perpetuated through principal and interest debt repayment.

Histogram 4. Unemployment rates in European countries

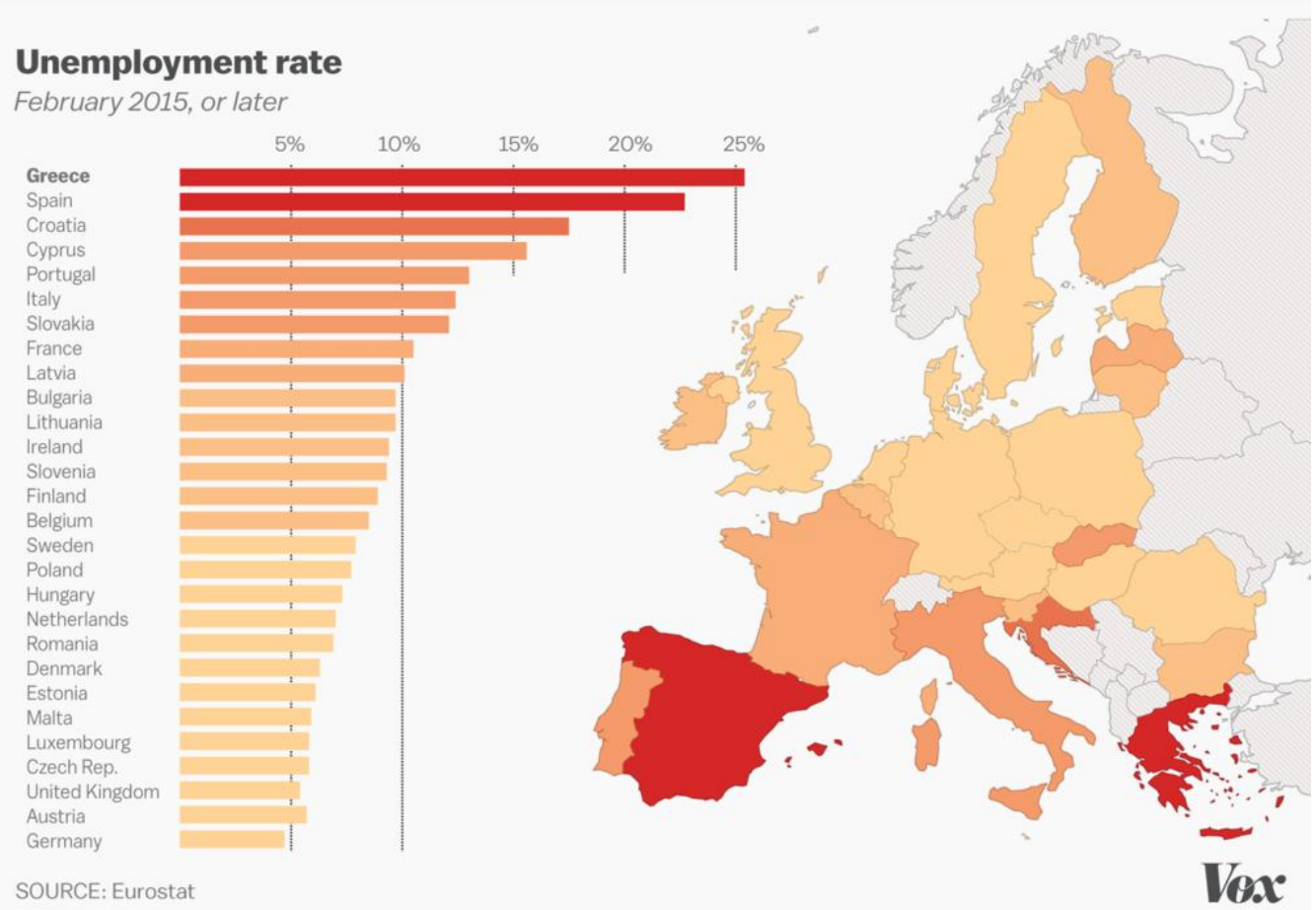


Histogram 5. Evolution of Greek debt as a percentage of the GDP

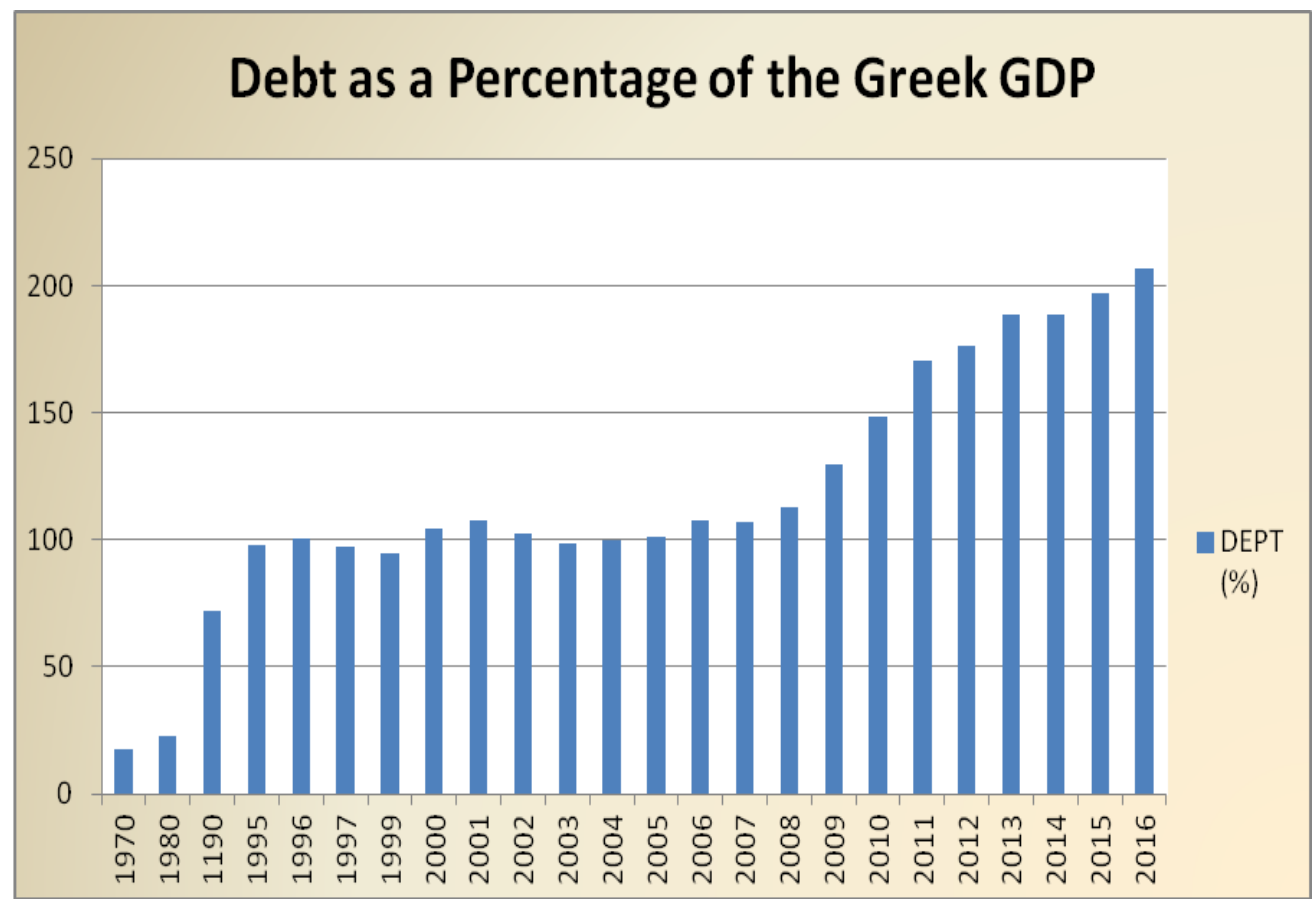

\section{Source: Eurostat}

The data referring to the annual payment of principal and interest debt to the lenders have not been officially disclosed. Yet, they can be estimated based on various statements occasionally given by foreign and Greek competent officials, which are rarely presented in the Greek media for obvious reasons. In April 2016, the Bloomberg Agency published a staggering histogram which shows that, within 2016, Greece must pay a total of 19 billion euro (Histogram 6). As it is also illustrated in the same histogram, the largest part of the payments has to be deposited during June and July 2016, when Greece has paid up 11 billion euro to the lenders.

In the Eurogroup summit of 23 May 2016, it was agreed that, the annual loan payments must be even higher: $15 \%$ of the GDP initially (25-26 billion euro) and $20 \%$ of the GDP (34-35 billion euro) latter on. Unofficial sources stated that, the whole matter will be discussed after the German elections of 2018, when the Greek heavy loans might be partly cut and extended in time. In any case, even though the Greek balance of payments currently has no more deficits as in the past, such huge loan liabilities as agreed in the Eurogroup summit are obviously impossible to be met by an economy which is in a free fall state. 
Histogram 6. Monthly evolution of loan liabilities for the repayment of the Greek debt

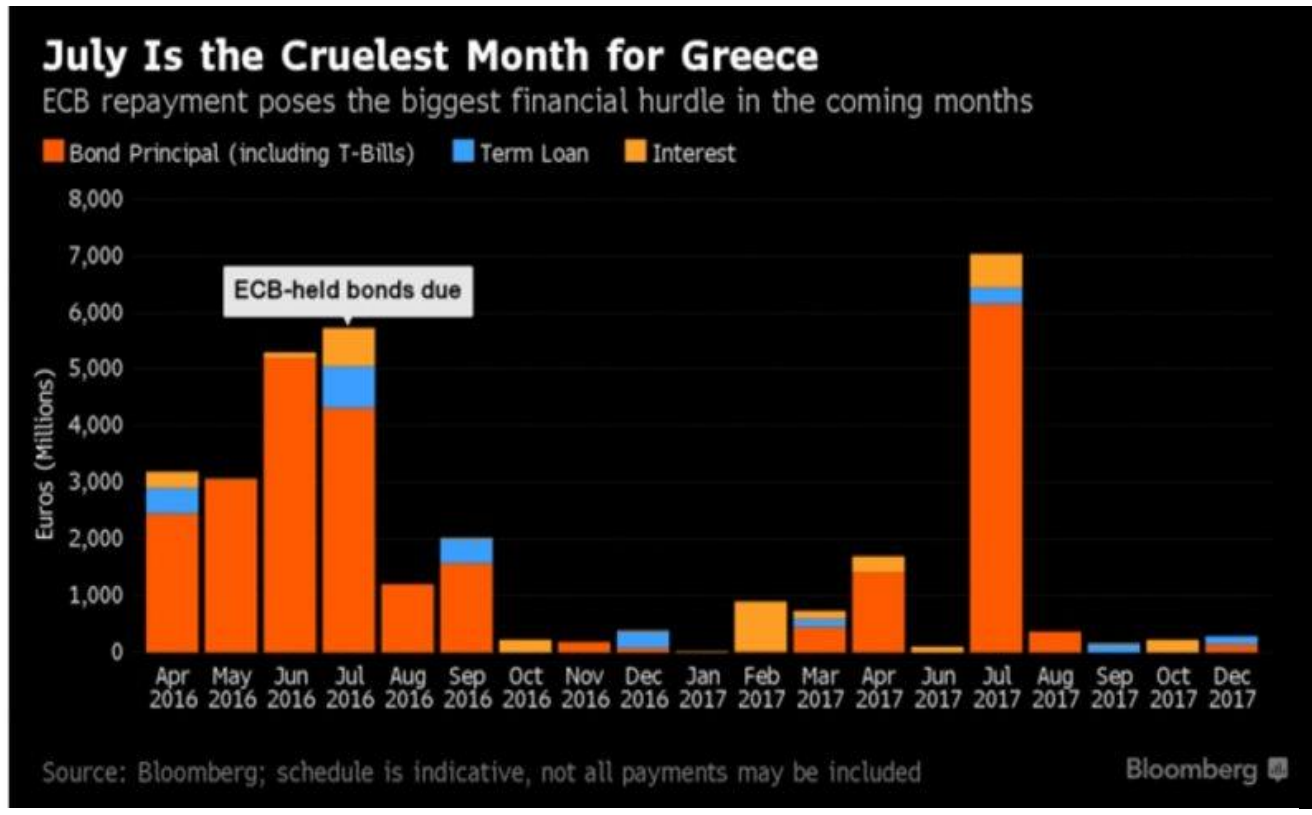

Source : Bloomberg

Since this is out of discussion, it appears that the lender' s plan B is to acquire, the larger part of such funds by the establishment of the "Superfund" under their command, where all state property of the country is to be included for 99 years and thus transforming the country to a modern "Banana Republic" ${ }^{3}$. In any case, the loss of funds from public property transformed to "Superfund" will deprive the Greek state budget from the influx of precious income and thus, new budget deficits will arise. Moreover, the ever more extreme austerity measures policies imposed by the lenders, will lead to further shrinkage of the economic cycle and deeper recession. It is an undeniable truth that Greece's colossal debt, which is increasingly growing, is not sustainable; a fact that is understood even by first year students of economics. This recession spiraling is irreversible and not any illusion of fake optimism can reverse it. Insofar the country is completely controlled by the distorted euro zone with the overvalued euro and harsh recession policy enforced, along with the disease of the fierce modern stock market capital; there is no possibility for the Greek economy to recover from the coma of destruction that has been trapped in. The considerably heavy debt of Greece, which is continuously growing, is completely

\footnotetext{
${ }^{3}$ The "Superfund" named "Greek Company of Partnership and Estate" basically controlled by the lenders, acquires for 99 years all state property such as ports, air ports, state land ,buildings, hotels touristic real estate, state companies of electricity, petroleum, gas, water, civil transport, railways etc.
} 
unfeasible to be paid up. This resembles less to reality and more to a science fiction scenario. It is hard to believe that the economic downhill of the Greek economy, can miraculously be averted. To put it simply, no such miracles can happen. The "Deus ex machina" common in ancient Greek theatre is not common to day.

\section{Most of the Loan Payments to Greece go to European Banks}

In accordance with Eurostat, the Greek public debt, was 317 billion euro (177.1\% of the GDP) in 2014, 320 billion euro (180.2\% of the GDP) in 2015 and is expected to be 319.6 billion Euros (173.4\% of the GDP) in 2016 (Table 4) ${ }^{4}$. In May 2016, the European School of Management and Technology (ESMT) based in Berlin, published a research report providing a descriptive analysis of where the Greek bailout money went since 2010( ESMT, May 2016). In accordance with the same study, out of the 220 billion Euros disbursed to Greece since the beginning of the economic crisis about 95\% ( 210,3 billion euro ) have gone mainly to German and French and less than 5\% (9.7 billion euro) went into the state budget for the benefit of Greek citizens. More analytically and in accordance with the same study, (also published in the German Handelsblatt newspaper in 5,May 2016), apart from the above sum of 9,7 billion, 86.9 billion Euros $(46,67 \%)$ of the bailout money went to repay old debts, 52.3 billion Euros $(28,08)$ for payment of interest, and 37.3 billion euro 20,03\%) for the recapitalization of Greek Banks.

In the latter case, this was necessary because of the large escape of capital abroad-a fact also related to the malfunction of the euro zone. (Pies 1 and 2). These findings where assumed and discussed but few knew as a fact, but now they are confirmed by the above valid study.

As stated in the same study, "for six years there are attempts to stop the Greek crisis with tougher measures and loans that require new loans to pay back the older ones. The cause of the failure is less in the side of the Greek government and more in the design of assistance programs. These calculations are raising doubts about the proper design of assistance programs, since the loans serviced debts, although Greece is the 2010 de facto bankrupt. In particular, the salvation of Greek banks proved disastrous for taxpayers. Overall, they channelled 37.3 billion euro in Greek banks from the two aid packages. But the aid is fully diminished. After the recapitalization by the PSI of 2012 the banks have lost almost $98 \%$ of their value in the stock market. Moreover, the resulting risk transfer from the private to the public sector and the subsequent risk transfer within the public sector from international organizations such as the ECB and the IMF to European rescue mechanisms such as

\footnotetext{
${ }^{4}$ According to the National Debt Clocks.Org, in May 2016, the Greek debt amounts to 344,5 billion euro and $210 \%$ of GDP. In accordance with the same source and in contrast with the official data of the Eurostat, the Greek GDP has fallen to 164 billion euro in the early 2016.
} 
the ESM, still constitute the most important challenge for the goal to achieve a sustainable fiscal situation in Greece". ${ }^{5}$

Pie 1. ESMT estimations about the distribution of the 186,2 billion euro loans to Greece

\section{ESMT estimations about the distribution(\%) of loans to Greece}

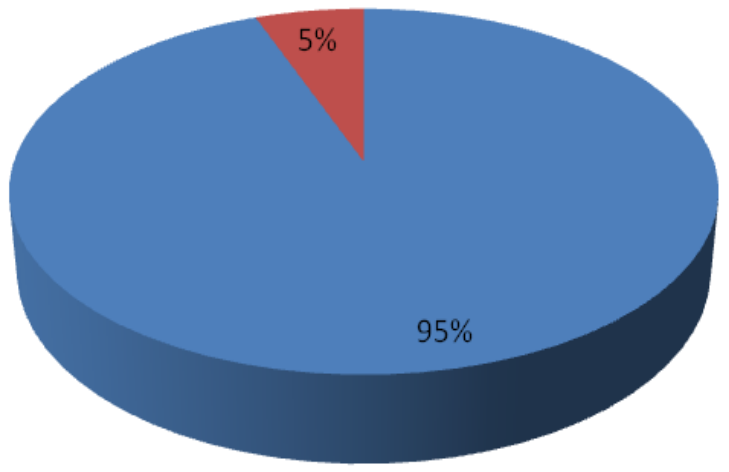

- German and French banks

- Greek state budget

Source: European School of Management and Technology, Berlin

\section{State Budget and Balance of Payments}

Over the last two years, the Greek state budget appears in balance or with a very minor surplus. The IMF, contrary to the Eurostat insists that, the small surplus of the Greek deficit is not real, mainly due to state debts to suppliers, pensioners etc. Nevertheless, it is a fact that the state budget balance has been improved and at least it does not show high deficits as it did in the past. Similarly, the country's balance of payments is also in surplus or more or less balanced. The government takes pride in

\footnotetext{
${ }^{5}$ The ex Prime Minister of Italy, Massimo D' Alema in a revealing interview to Skype in $6 / 8 / 2015$ pointed out that ". $€ 220 \mathrm{bn}$ out of the $€ 250 \mathrm{bn}$ of aid to Greece has gone directly to the German, French and Italian banks, as interest paid to the lenders. In reality, when we say that we're paying the Greeks' pensions, that's not true - no, we're paying the German banks. It goes a roundabout way, yes, it does a little trip, but the Greeks don't even get a whiff of it. This mechanism cannot last for any length of time - it is not working and will not work".
} 
itself regarding these developments, yet it does not broadly communicate them. If this information gets widely known, then it will allay the simplistic but rather popular myth, foreseeing the country's destruction upon returning to the the national currency the drachma, supposedly due to lack of exchange currency, food, medicines, fuels, etc.

In fact, the outcomes of the state budget and balance of payments has been improved mainly because of the wide decrease in oil prices, since fuel imports were responsible for approximately more than one third of the balance of payments deficit up to the end of 2013. In the same year, fuel prices were about 100 euro per barrel, whereas in 2015 it has fallen down to 30 euro. While the price of fuel importing was decreased by $70 \%$ approximately, their final price regarding domestic consumption was only down by $30 \%$ due to high taxation. Therefore, on one hand, the balance deficit was significantly reduced and on the other, public revenues were also higher due to a $70 \%$ increase of taxation in fuels, which had positive consequences for the state budget.

Pie 2. Analytical ESMT estimations about the distribution of the 186,2 billion euro loans to Greece

\section{Analytical ESMT estimations about the distribution of the 186,2 billion euro loans to Greece}

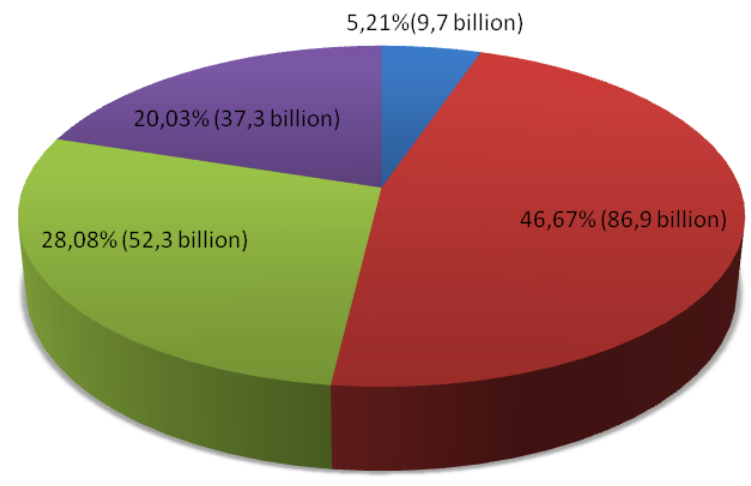

- Greek state budget

- Repayment of old debts

a Payment of interest

- Recapitalization of Greek Banks

Source: European School of Management and Technology, Berlin

The improvement of the state budget has also been caused, to a lesser extent, by the harsh austerity measures taken through the numerous provisions of the bailout agreements and specifically through the memorandum in July 2014, which primarily concerns cuts in wages, pensions, social care provisions and state commissions, mainly in the healthcare sector. Moreover, it is due to significant delays in paying 
suppliers and pensioners, even if their respective provisions have vastly decreased. Capital controls imposed in June 2015 had a positive role in the amelioration of the state budget as well, since they drastically limited imports and facilitated the detection of a part of taxable amounts. However, the tremendous increase of direct and indirect taxation and the intensification of tax controls and penalties during the years 2013-2016, do not seem to have benefited state funds, due to the great recession and shrinkage of the economic cycle and total taxable income.

\section{The Friendly Grexit as a Realistic Solution}

As things stand today and given the present international geopolitical balance, the friendly Grexit, temporary or permanent, is the proper alternative for Greece ${ }^{6}$. A friendly Grexit is a velvet divorce and does not entail financial and chiefly geopolitical risks, which could accompany a unilateral suspension of payments and unregulated transition to national currency. As long as it is properly implemented, it will supply the necessary liquidity, whose lack utterly destroys Greek economy.

Moreover, it does not cause any serious side effects to the euro zone, while it additionally prevents the continuous imposition of extreme austerity policies that only lead to spiraling into recession, endless impoverishment and permanent economic immobilization, which is also harmful for the lenders. The state budget surplus and the harmonization of the balance of payments that have been achieved mostly because of the significant decrease in imported fuel price and to lesser extent by the enforcement of austerity measures, constitutes a golden opportunity for the promotion of this suggested plan.

The friendly Grexit and the coordinated transition to drachma, implies a controlled bankruptcy, suspension of debt payments and negotiations for cutting and extending its repayment period. During the initial negotiation days, the government must be ready to provide liquidity to the economy through the issuing of non-interest state

${ }^{6}$ Within the context of the underlying "currency war" between the dollar and the euro, the German Minister of Finance, Wolfgang Schäuble has publicly argued in favor of a friendly Grexit for five years, offering support regarding the conservation of the drachma's exchange rate to the euro and its devaluation of the national currency by 25\% ( 1 drachma $=0.75$ Euros), which will be particularly beneficial for the competitiveness of Greek economy. In order for the exchange rate to be secured and for the new drachma not to be further devalued, Schäuble has made a commitment to initially provide to Greece 25 billion euro and 25 billion more at a second stage, namely 50 billion euro in total. In such an event, he appears willing to discuss a debt haircut and restructure, while in previous statements he has referred to the possibility of paying war reparations refer to the WWII compensations that Germany owns to Greece because of its occupation by the $3^{\text {rd }}$ Reich, during the period of 1940-45, which have not been paid up to Greece and still remain due. 
bonds at a ratio of 1: 1 in relation to the euro. Existing capital controls imposed by the euro zone and the recent widespread transactions with electronic money through the banks, could be used properly. By possessing the necessary domestic currency liquidity, the Greek government will be in a better negotiation position for the friendly Grexit, the necessary cut of the debt and the extension of its repayment period.

The next step will be the issuing of the new drachma devaluated at $25 \%$ in relation to the euro, as a necessary precondition for regaining the lost competitiveness of the economy. In order to avoid the dangers of hyperinflation, the amount of new drachma produced, must not exceed a certain level of the M2 that is no more than $20 \%$ of the GDP $34-35$ billion euro) ${ }^{7}$. The euro may continue to be used as a parallel currency for a period decided in accordance with the result of negotiations and economic trends.

The widespread fears for an initial vacuum of imported necessary goods do not exist, since at present, the total balance of payments for goods and services has shown a small surplus. (Bank of Greece, Report of the Director, 2014, page 115). Capital controls could contribute to improving the balance of payments, since through them it is possible to facilitate exports and reduce imports of non-essential luxury goods.

The black economy and illegal work will be limited necessarily. Only legal immigrants could export a certain amount of taxpayer exchange and this alone, will prevent the inflow of excess number of economic immigrants without legal residence and work permit. Internal economic transactions may supported by the issuing of the national currency. In the same way, the banks may be re-capitalised and provide the desperately needed liquidity to the economy. Low and medium incomes may be increased gradually, following labour productivity and GDP growth trends.

Government spending restrictions, the combat of corruption, impunity, bureaucracy, tax evasion and the strengthening of productive investments, are also necessary. At present, in the days of the Modern Greek Tragedy, the country must leave behind the obsessions, the hook, and the absurdity of the "euro at all costs" that goes hand in hand with the barbaric Memorandum. After learning the lessons from past mistakes, the stubborn insistence of being a member of the euro zone deadlock is a fatal illusion. Nor is there any solution by the ultra left "all or nothing" obsessions which

\footnotetext{
${ }^{7}$ The M2 is briefly defined as the measure of money supply that includes cash and checking deposits (M1) as well as near money. "Near money" in M2, includes savings deposits, money market mutual funds and other time deposits, which are less liquid and not as suitable as exchange mediums but can be quickly converted into cash or checking deposits.
} 
shift the termination of the Modern Greek Tragedy in infinite future. The friendly Grexit must and will come sooner or later.

\section{References}

Alesina, A. \& R. Barro. (2002). Currency unions. Quarterly Journal of Economics 117 (2): 409-436.

Athanasenas, A., Chapsa, X. and Michailidis, A. (2015). Investigating Social Protection Convergence in the EU-15: A Panel Data Analysis. European Research Studies Journal, 18(2), 79-96.

Bank of Greece, Statistics, Special Reports, Studies and Reports of the Director.

Blanchard, O . (2015). Greece: Past critiques and the path forward. IMF.

Bloomberg, (2016). Montlhy evolution of loan liabilities of the Greek debt.

Bootle R., (2012). Leaving the Euro: a Practical Guide. Capital Economics, A submission for the Wolfson Economics Prize MMXII.

Chionis, D. (2015). Reform and growth or growth and reform. ICABE.

(ELSTAT), Greek Statistical Authority, Statistics and Reports.

Eurogroup summit 23,May 2016, Agreement.

European School of Management and Technology ( ESMT, May 2016), White Paper : Where did the Greek bailout money go ? (Jorg Rocholl, Alex Stahmer).

Eurostat statistics and surveys 2015, 2016.

Engelbert, S., (2011). Peripheral Europe's debt and German wages. Discussion paper 29.Dept.of Economics,SOAS,University of London.

Ghosh , J. (2015). The failed project of Europe. Triple Crisis I.M.F. Economicoutlook.

Johnson, S. (2015) The end of the Europe is not about austerity. The New York Times.

Jonung, L. and Drea, E. (2009). The Euro: It can't happen. It's a bad idea. It won't work. US economists on the EMU, 1989-2002. Economic Papers.

Katsanevas, Th. (2015). Greece and the euro zone crisis.ICABE, www.icabe.gr

Katsanevas, Th. (2106). The Modern Greek Tragedy and the necessary Grexit. Lambert Academic Publishing

Katsinos, A., Mariolis, T. (2012). Switch to devalued drachma and cost-push inflation:A simple input-output approach to the Greek case," Modern Economy, Vol. 3 No. 2, , pp. $164-170$

Krugman, P. (2012). End this depression now. Melrose Road Partners.

Lachman, D. (2011). Can the euro survive? London: Legatum Institute.

Lapavitsas, C., Kaltenbrunner, A., Lambrinidis, G. (2010). The Eurozone between austerity and default, Research on Money and Finance.

Liapis, K., Rovolis, A., Galanos, C. and Thalassinos, I.E. (2013). The Clusters of Economic Similarities between EU Countries: A View Under Recent Financial and Debt

Crisis. European Research Studies Journal, 16(1), 41-66.

Massimo D'Alema, (6/8/2015), interview to Skype.

Ministry of Economics of Greece. Budget Draft 2016.

Muller, D. (2015).Showdown.

Mundell, R. (1961). A theory of optimum currency areas. American Economic Review.

National Debt Clocks Org., May 2016.

National Statistical Authority of Greece, statistics 2014, 2015, 2016.

Negreponti-Delivani ,M (2014). The killing of Greece. Ianos and L' Harmattan.

O Rourke, K.H. (2014). Wither the euro? Finance and Development, Vol 51.

Richards,J. (2012). Currency wars. The making of the next global crisis. Amazon. 
Rocholl, J., Stahmer, A. (2016). Where did the bailout money go? The European School of Management, Berlin.

Rogoff, K. (2015). The Modern Greek Tragedy. VOX CEPS; s Policy Portal.

Rodrik, D. (2015). Structural reforms and Greece : Lessons from other countries. Athens, Oct. www.inerpost.gr.

Rupeika-Apoga, R. and Nedovis Uraev, R. (2015). The Foreign Exchange Exposure of NonFinancial Companies in Eurozone: Myth or Reality? International Journal of Economics and Business Administration, 3(1), 54-66.

Saratrin, O.T. (2012). Europe does not need euro. Focus.

Sinn H.W. (2013). Greece should exit the Eurozone as soon as possible and be offered a return ticket!. Open Europe, http://klauskastner.blogspot.gr.

Skarperdas, S. (2011). Seven myths about the Greek debt crisis,"www.socsci.uci.edu/skarpedasmythsWP1011.

Thalassinos, I.E. and Pociovalisteanu, M-D. (2009). The Structural Funds and the Economic and Social Cohesion Process. Annals-Economy Series 1, 313-330.

Thalassinos, I.E., Deceanu, L. and Pintea, M. (2010). New Dimensions of Country Risk in the Context of the Current Crisis: A Case Study for Romania and Greece. European Research Studies Journal, 13(3), 225-236.

Thalassinos, I.E., Ugurlu, E. and Muratoglu, Y. (2012). Income Inequality and Inflation in the EU. European Research Studies Journal, 15(1), 127-140.

Thalassinos, E.P. (2014). Credit Default Swaps and Sovereign Debt in Eurozone. Chapter book in Risk Management: Strategies for Economic Development and Challenges in the Financial System,(eds), D. Milos Sprcic, Nova Publishers, 255-278, ISBN: 978163321539-9; 978-163321496-5.

Thalassinos, I.E., Liapis, K. and Thalassinos, E.J. (2014). The role of the rating companies in the recent financial crisis in the Balkan and black sea area. Chapter book in Economic Crisis in Europe and the Balkans, 79-115, Contributions to Economics, Springer International Publishing, DOI: 10.1007/978-3-319-00494-5-6.

Thalassinos I.E. and Dafnos G. (2015). EMU and the process of European integration: Southern Europe's economic challenges and the need for revisiting EMU's institutional framework. Chapter book in Societies in Transition: Economic, Political and Security Transformations in Contemporary Europe, 15-37, Springer International Publishing, DOI: 10.1007/978-3-319-13814-5_2.

Thalassinos, I.E., Th. Stamatopoulos, D.T. and Thalassinos, E.P. (2015). The European Sovereign Debt Crisis and the Role of Credit Swaps. Chapter book in The WSPC Handbook of Futures Markets (eds) W. T. Ziemba and A.G. Malliaris, in memory of Late Milton Miller (Nobel 1990) World Scientific Handbook in Financial Economic Series Vol. 5, Chapter 20.

Thalassinos, I.E., Pintea, M., Raţiu, I.P. (2015). The Recent Financial Crisis and Its Impact on the Performance Indicators of Selected Countries during the Crisis Period: A Reply. International Journal of Economics and Business Administration, 3(1), 3-20.

The Minister of the Bank of Greece Reports, 2014, 2015.

Van Overtveldt J., (2012). The end of the Euro: the uneasy future of the European Union. Amazon.

Volcker, P. Gyohten, T. (1993). Changing fortunes. The world's money and the threat to American leadership. Amazon.

Weeks, J. (2013). Join the euro? Yes, for lower growth.www.socialeurope.eu http://www.socialeurope.eu/2013/08/join-the-euro-yes-for-lower-growth/

World Bank Factbook $(2014,2015)$. 